\title{
Dwie wizje roli Kościoła w realiach komunistycznej dyktatury - wymiana korespondencji pomiędzy bp. Ignacym Tokarczukiem ordynariuszem przemyskim a sekretarzem Episkopatu Polski bp. Bronisławem Dąbrowskim w 1979 r.
}

Biskup Bronisław Dąbrowski, sekretarz Episkopatu Polski i bp Ignacy Tokarczuk, ordynariusz przemyski pełnili w polskim Kościele pod koniec lat siedemdziesiątych bardzo istotną rolę. Obydwaj byli członkami kierowniczego gremium polskiego Kościoła, czyli Komisji/ Rady Głównej Episkopatu Polski ${ }^{1}$. Pierwszy z wymienionych hierarchów zasiadał w niej od 1969 r., gdy został mianowanym sekretarzem Episkopatu, podczas gdy bp Tokarczuk był jej członkiem nieprzerwanie od 1967 r., do Komisji Głównej wszedł zaraz po tym, jak obją swoja diecezję.

Biskup Dąbrowski w Episkopacie Polski odpowiadał za kontakty z władzami komunistycznymi ${ }^{2}$, kontynuował pod tym względem obowiązki swojego

\footnotetext{
${ }^{1}$ Szerzej zob. Archiwum Archidiecezji Warszawskiej (dalej: AAW), Sekretariat Prymasa Polski (dalej: SPP), 04/31-36, Rada Główna Episkopatu Polski. Zob. też: J. Żaryn, Dzieje Kościoła katolickiego w Polsce (1944-1989), Warszawa 2003; R. Łatka, Polityka władz PRL wobec Kościoła katolickiego w województwie krakowskim w latach 1980-1989, Kraków 2016, s. 66; idem, Rada Gtówna Episkopatu Polski wobec przedsierpniowej opozycji (1976-1981), „Pamięć i Sprawiedliwość” 2017, nr 1, s. 110-112.

${ }^{2} \mathrm{Na}$ ten temat zob. P. Raina, Rozmowy z władzami PRL. Arcybiskup Dabrowski w stużbie Kościoła i narodu, t. I: 1970-1981, t. II: 1982-1989, Warszawa 1995; idem, Wizyty apostolskie Jana Pawła II w Polsce. Rozmowy przygotowawcze Watykan - PRL - Episkopat, Warszawa 1997; idem, Rozmowy biskupa Bronistawa Dabrowskiego z władzami PRL. Stolica Apostolska reguluję organizacje kościelna na Ziemiach Zachodnich i Pótnocnych Polski, Olsztyn 1998; idem, Troska o internowanych. Interwencje abp. Dabrowskiego u gen. Kiszczaka 1982-1989, Warszawa 1999; idem, Arcybiskup Dabrowski - rozmowy watykańskie, Warszawa 2001; idem, Stan wojenny w zapiskach arcybiskupa Dabrowskiego, Warszawa 2006; idem, Arcybiskup Bronistaw Dabrowski. Portret, Warszawa 2008; Obrońca Kościoła
} 
nauczyciela i mistrza bp. Zygmunta Choromańskiego, którego był najbliższym współpracownikiem w latach 1950-1968 jako dyrektor Sekretariatu Episkopatu Polski ${ }^{3}$. Po jego śmierci obją godność sekretarza Episkopatu i regularnie spotykał się z dygnitarzami partyjnymi odpowiedzialnymi za relacje państwo-Kościół ${ }^{4}$. Funkcję tę sprawował przez ponad ćwierć wieku w latach 1969-1993, pozostając głównym negocjatorem kościelnym w relacjach z władzami PRL (Konferencja Episkopatu pięciokrotnie wybrała bp. Dąbrowskiego na wspomniane stanowisko). Cieszył się olbrzymim zaufaniem kard. Wyszyńskiego, który wysoko cenił jego pracę. Świadczy o tym fakt, że prymas już w 1963 r. w czasie rozmowy z papieżem Pawłem VI wymienił go jako jednego $\mathrm{z}$ trzech swoich potencjalnych następców na wypadek ponownego aresztowania przez władze komunistyczne lub swojej śmierci ${ }^{5}$.

Biskup Tokarczuk dał się poznać w okresie swojej biskupiej posługi jako radykalny antykomunista i zdecydowany przeciwnik władz Polski „ludowej”’.

i Narodu. Wspomnienie o ks. abpie Bronistawie Dabrowskim, red. M. Koper, W. Świąkiewicz, Warszawa 1998; „Instaurare omnia in Christo”. Odnowic wszystko w Chrystusie. Ks. Abp Bronistaw Dabrowski 1917-1997, Warszawa 1998.

${ }^{3}$ P. Raina, Wprowadzenie, w: idem, Rozmowy z wtadzami PRL..., t. I, s. 9-10. Na temat bp. Choromańskiego szerzej zob. M.G. Smoliński, Biskup negocjator. Zygmunt Choromański (1892-1968), Warszawa 2014. Warto podkreślić, że bp Choromański współkonsekrował w 1962 r. bp. Dąbrowskiego.

4 Jak wspominał kard. Józef Glemp: „Trudnymi negocjacjami kierował Arcybiskup Dąbrowski. Były to pertraktacje długie i żmudne. Dokumenty zajmuja wiele regałów archiwalnych. Bogu dziękujemy za skuteczność tych zabiegów, za szukanie autentycznego kompromisu, u którego fundamentów leżało wydobycie dobrej woli w stosunku do człowieka, mimo różnic w patrzeniu na niego. To właśnie te negocjacje doprowadziły do pięciu pielgrzymek papieskich do Polski, jakże owocnych dla ducha narodowego i podstaw rozwoju na chrześcijańskich zasadach. Arcybiskup był twardym negocjatorem, szczególnie wtedy, gdy trzeba było walczyć o prawa «Solidarności», o obronę internowanych w czasie stanu wojennego i inne sprawy. Nigdy jednak, stając w obronie Kościoła, nie obrażał rozmówców, po prostu szanował człowieka o innych poglądach”. J. Glemp, Jego życie byto ustawicznym postugiwaniem Ewangelii, w: Obrońca Kościoła..., s. 16-18.

${ }^{5}$ Pozostałymi dwoma wymienionymi przez prymasa Wyszyńskiego kandydatami byli bp Jerzy Stroba i bp Jerzy Modzelewski. P. Raina, Wprowadzenie..., s. 13. Warto również podkreślić, że za trudnego rozmówcę uważali go dygnitarze partyjni. Wspominał o tym Aleksander Merker, jedna z najważniejszych postaci w Urzędzie ds. Wyznań. A. Merker, O arcybiskupie Bronistawie Dabrowskim - i nie tylko o nim, w: P. Raina, Arcybiskup Bronistaw Dabrowski. Portret..., s. 290-292.

${ }^{6}$ Powstała już na ten temat dość obszerna literatura. Zob. I. Tokarczuk, Wytrwać i zwyciężyć, Paryż 1988; Księga jubileuszowa 25 lat pasterskiego postugiwania ks. Biskupa Ignacego Tokarczuka, red. J.F. Adamski, M. Rudnicka, Brzozów-Stalowa Wola 1991; J. Bar, A. Szal, Nowe kościoty diecezji przemyskiej $w$ jej dawnych granicach powstałe w latach 1966-1992, Przemyśl 1993; I. Tokarczuk, W starciu z totalitaryzmem. Rozmowy przeprowadził Tadeusz Fredro-Boniecki, Paryż 1994; A. Szypula, Historia nowych kościołów w Diecezji Przemyskiej 1966-1993, t. I-IV, Rzeszów 1997-1998; I. Tokarczuk, Kazania pod specjalnym nadzorem, oprac. L. Żbikowska, Marki-Struga 1998; I. Tokarczuk, Z przemyskiej „twierdzy”, t. I-II, oprac. L. Żbikowska, Marki 1999; J. Żaryn, Bp Ignacy Tokarczuk, w: Opozycja w PRL. 
Arcybiskup Tadeusz Gocłowski trafnie scharakteryzował tego typu postawę swojego współbrata w biskupstwie: „Bp. Tokarczuk był radykalnym antykomunista. Radykalizm ten był unikalny na tle Episkopatu Polski. Nikt spośród jego przedstawicieli nie miał wątpliwości co do charakteru komunizmu. Posiadaliśmy też wspólną ocenę ad rem Patriae. W kwestii oceny sytuacji zgadzaliśmy się z bp. Tokarczukiem, ale co do metody postępowania wobec komunizmu już niezupełnie. Bp. Tokarczuk był zaś konsekwentny co do treści, jak i formy. Stosowane przez niego metody nie były powszechnie popierane w Episkopacie Polski”"

Wymiana korespondencji, jaka miała miejsce w 1979 r., odbywała się w kontekście ostrej kampanii propagandowej władz PRL wymierzonej w działalność bp. Tokarczuka ${ }^{8}$. Ordynariusza przemyskiego kłamliwie przedstawiano jako współpracownika Gestapo w czasie II wojny światowej. Ostre zarzuty przeciwko działalności bp. Tokarczuka stawiał w czasie rozmowy z bp. Dąbrowskim premier Jaroszewicz ${ }^{9}$. Wynikało to z dwóch zasadniczych powodów: jego aktywności na polu budownictwa sakralnego oraz kontaktów i współpracy z opozycją przedsierpniową ${ }^{10}$.

Stownik biograficzny 1956-89, t. II, Warszawa 2002, s. 337-339; Arcybiskup Ignacy Tokarczuk w oczach spoteczeństwa, red. J. Zimny, Sandomierz 2003; „Studia Rzeszowskie” 2003, t. X; S. Bober, Persona non grata. Biskup Ignacy Tokarczuk i władze PRL, Lublin 2005; idem, Krytyka PRL w kazaniach biskupa Ignacego Tokarczuka, „Dzieje Najnowsze” 2006, nr 1, s. 123-140; A. Garbarz, Działalność duszpastersko-spoteczna arcybiskupa Ignacego Tokarczuka, Rzeszów 2006; P. Chmielowiec, M. Krzysztofiński, Abp Ignacy Tokarczuk. Trzeba oprzeć wszystko na prawdzie, w: Nigdy przeciw Bogu. Komunistyczna bezpieka wobec biskupów polskich, red. J. Marecki, F. Musiał, Warszawa-Kraków 2007, s. 417-622; P. Chmielowiec, Dziatania operacyjne Stużby Bezpieczeństwa wobec biskupa Ignacego Tokarczuka $i$ kurii biskupiej w Przemyślu, w: Aparat bezpieczeństwa wobec kurii biskupich w Polsce, red. A. Dziurok, Warszawa 2009, s. 282-316; Nie można zdradzić Ewangelii. Rozmowy z abp. Ignacym Tokarczukiem, oprac. M. Krzysztofiński, Rzeszów-Kraków 2013; B. Lipian, Wybrat Go Jezus... Ks. Arcybiskup Ignacy Tokarczuk (1918-2012), Jarosław 2013; I. Tokarczuk, Kochatem tych ludzi catym sercem $i$ oddaniem. Wspomnienia z lat 1918-1976, oprac. J. Wołczański, Lwów-Kraków 2014; Non omnis moriar. Abp Ignacy Tokarczuk we wspomnieniach, oprac. M. Krzysztofiński, Rzeszów-Lwów 2016; D. Iwaneczko, Zmierzch dekady Gierka. Polska południowo-wschodnia 1975-1980, Rzeszów 2016, s. 230-264.

${ }^{7}$ Relacja abp. Tadeusza Gocłowskiego, w: Non omnis moriar..., s. 155-156. Por. Nie można zdradzić Ewangelii..., s. 62. Mimo tych różnic bp Tokarczuk był ceniony w Episkopacie Polski, o czym świadczy fakt, iż nieprzerwanie zasiadał w kierowniczym gremium polskiego Kościoła, czyli Radzie Głównej (1967-1993). M. Krzysztofiński, Wstęp, w: Nie można zdradzić Ewangelii..., s. 11.

8 Władze PRL groziły postawieniem bp. Tokarczuka przed sądem za „nielegalną działalność”. P. Raina, Rozmowy z wtadzami PRL..., t. I, s. 329-330.

9 AAW, SPP, 04/34, Rada Główna Episkopatu Polski, Sprawozdanie z rozmowy przeprowadzonej w Urzędzie Rady Ministrów przy Al. Ujazdowskich z Panem Piotrem Jaroszewiczem, Prezesem Rady Ministrów PRL, Warszawa 19 VIII 1979, k. 191-196.

${ }^{10}$ Ibidem, Rada Główna Episkopatu Polski, Sprawozdanie z rozmowy przeprowadzonej w Urzędzie Rady Ministrów przy Al. Ujazdowskich z Panem Piotrem Jaroszewiczem, Prezesem Rady Ministrów PRL, Warszawa 19 VIII 1979, k. 191. 
Sekretarz Episkopatu, a przede wszystkim prymas Wyszyński nie podzielali poglądów bp. Tokarczuka dotyczących opozycji i części jego metod działania wobec komunistycznych dygnitarzy ${ }^{11}$, ale wobec ataków władz na ordynariusza przemyskiego wspierali go i odpierali zarzuty władz, szczególnie na polu walki o nowe świątynie ${ }^{12}$. Było to widoczne w czasie spotkań bp. Dąbrowskiego z dygnitarzami partyjnymi, ministrem Kąkolem i premierem Jaroszewiczem w lipcu i sierpniu 1979 r., w czasie których wprost zapowiedział, że działania represyjne wymierzone $\mathrm{w}$ bp. Tokarczuka zaszkodza samym ich kreatorom, gdyż w jego obronie stanie cały Episkopat Polski ${ }^{13}$. W odpowiedzi premier twierdził, że jedyną przeszkodą w normalizacji stosunków jest postawa ordynariusza przemyskiego i deklarował, że „Jeżeli bp. Tokarczuk się nie uspokoi i Episkopat nie zechce spowodować by nie zadrażniał stosunków będziemy musieli uważać, że Episkopatowi nie zależy na normalizacji stosunków"14. Sekretarz Episkopatu zareagował w zdecydowany sposób na takie dictum, zauważając, że to nie bp Tokarczuk rozpoczał ,politykę zadrażniania”, a władze wojewódzkie, które przeciwstawiały się budowie świątyń na potrzeby religijne mieszkańców diecezji: „Czy Pan Premier uważa, że Biskup Przemyski mógł potulnie poddać się tej polityce kacyków rzeszowskich? To władze rzeszowskie sa winne tej sytuacji, a nie biskup. Jeżeli teraz chca sankcji to niech je stosuja, ale niech Pan Premier przyjmie do wiadomości, że cały Episkopat stanie po stronie Biskupa Przemyskiego. Całe społeczeństwo i cały świat go poprze. [...] Wy macie siłę fizyczną i możecie jej użyć, ale ani Biskup Tokarczuk, ani Episkopat sie jej nie ulęknie. Ubolewam tylko nad tym, że znowu sięgacie do pogróżek"15. Prymas z kolei nie tylko nie odcinał się od

${ }^{11}$ Ibidem, Rada Główna Episkopatu, List Sekretarza Episkopatu bp. Bronisława Dąbrowskiego do bp. Ignacego Tokarczuka, 22 VIII 1979, k. 197-200; R. Łatka, Rada Gtówna Episkopatu...

12 AAW, SPP, 04/34, Rada Główna Episkopatu Polski 1979, Pro Memoria skierowane do premiera Jaroszewicza, 23 VIII 1979, k. 182; ibidem, Rada Główna Episkopatu Polski Protokół Rady Głównej Episkopatu Polski z 4 IX 1979, k. 270-271; Archiwum Archidiecezji Gnieźnieńskiej (dalej: AAG), S. Wyszyński, Pro Memoria 1979, Zapis z 4 IX 1979.

${ }^{13}$ AAW, SPP, 04/34, Rada Główna Episkopatu Polski, Sprawozdanie z rozmowy przeprowadzonej w Urzędzie Rady Ministrów przy Al. Ujazdowskich z Panem Piotrem Jaroszewiczem, Prezesem Rady Ministrów PRL, Warszawa 19 VIII 1979, k. 191-196; P. Raina, Rozmowy z wtadzami PRL..., t. I, s. 330.

${ }^{14}$ AAW, SPP, 04/34, Rada Główna Episkopatu Polski, Sprawozdanie z rozmowy przeprowadzonej w Urzędzie Rady Ministrów przy Al. Ujazdowskich z Panem Piotrem Jaroszewiczem, Prezesem Rady Ministrów PRL, Warszawa 19 VIII 1979, k. 194.

15 Ibidem, k. 195. Por. Sprawozdanie z rozmowy w Urzędzie Rady Ministrów przy Al. Ujazdowskich z Panem Piotrem Jaroszewiczem, Prezesem Rady Ministrów PRL, Warszawa 28 VII 1979, w: P. Raina, Rozmowy z wtadzami PRL..., t. I, s. 349-353. W swoim liście do bp. Tokarczuka sekretarz Episkopatu podkreślał, że ordynariusz przemyski nie byłby „nietykalny”, gdyby za nim nie stał cały Episkopat. AAW, SPP, 04/34, Rada Główna Episkopatu, List Sekretarza Episkopatu bp. Bronisława Dąbrowskiego do bp. Ignacego Tokarczuka, 22 VIII 1979, k. 200. 
ordynariusza przemyskiego, ale mówił przedstawicielom władz, że powinien być on odznaczony za działalność na trudnym terenie, mającym tendencje do „ukrainizowania się"16. W czasie rozmowy z K. Kąkolem z 12 października w odpowiedzi na uwagę swojego rozmówcy, że być może władze podejma interwencje w diecezji przemyskiej, kard. Wyszyński zareagował w zdecydowany sposób: „Uważam, że to rozpocznie sprawę oporu społeczeństwa od nowa. Radzę ustapić, nie atakować Biskupa, gdyż społeczeństwo upomni się o Biskupa. [...] Na pewno lud nie wystapi p-ko Biskupowi, choćby zmontowano akcje prasową i administracyjna. Radzę władzom adm., by sprawę tę same wyciszyły"17.

Prezentowane poniżej źródła archiwalne: list bp. Tokarczuka do bp. Dąbrowskiego z 30 VII 1979 r. i odpowiedź sekretarza Episkopatu z 22 VIII 1979 r. są niezwykle ważnym dokumentem historycznym, który jak w soczewce pokazuje różnice zdań panujące w Episkopacie Polski na temat strategii działania wobec władz komunistycznych i udzielenia wsparcia opozycji politycznej. Wymiana korespondencji ukazuje również dwie odmienne wizje strategii stosunku polskiego Kościoła do rzeczywistości politycznej PRL. Cele obaj hierarchowie mieli takie same, czyli utrzymanie niezależności Kościoła od władz Polski „ludowej” i poszerzenie podmiotowości społeczeństwa w realiach komunistycznego reżimu. O wspólnocie poglądów polskich biskupów na ten temat mówił po latach bp Tokarczuk w następujący sposób: „W stosunku do komunizmu wszyscy byli jednomyślni, wszyscy wiedzieli czym jest komunizm i do czego dąży, więc w tej zasadniczej kwestii różnic nie było. Różnice bywały w szczegółowych sprawach. Każdy reprezentował swoje środowisko, swój punkt widzenia i swoje racje. A przy czym z czego wszyscy zdawaliśmy sobie sprawę, prawda, władzy zależało, by nas w Episkopacie poróżnić. Wiele wysiłku w to wkładali uciekajac się do najpodlejszych metod"18. Drogi do osiagnięcia tego rezultatu były w przekonaniu bp. Dąbrowskiego i bp. Tokarczuka jednak odmienne. Ten pierwszy uważał, że należy skupić się na misji Kościoła i twardym negocjowaniu z władzami. Podczas gdy ordynariusz przemyski był przekonany, że tylko bezkompromisowa walka z systemem komunistycznym może się przyczynić do zmian poszerzających wolność społeczną i z tego względu udzielał wsparcia opozycji przeciwko rządom PRL.

List bp. Tokarczuka jest naładowany emocjami i napisany został z pewnością w stanie silnego wzburzenia. Można wnioskować, że z tego powodu znalazły się w nim daleko idące oskarżenia sformułowane pod adresem

${ }^{16}$ Ibidem, Rada Główna Episkopatu Polski 1979, Protokół Rady Głównej Episkopatu Polski z 4 IX 1979, k. 270-271.

${ }_{17}$ AAG, S. Wyszyński, Pro Memoria 1979, Zapis z 12 X 1979. Analogiczna postawę zajmował bp Dąbrowski, który ze S. Kanią spotkał się tydzień później. Sprawozdanie z rozmowy [ze Stanisławem Kania] w Sulejówku w dniu 20 X 1979, w: P. Raina, Rozmowy z władzami PRL..., s. 360-361.

${ }^{18}$ I. Tokarczuk, W starciu z totalitaryzmem..., s. 108. 
bp. Dąbrowskiego. Nie można bowiem inaczej traktować jego uwag, że sekretarz Episkopatu uległ naciskowi dygnitarzy partyjnych, z którymi prowadził rozmowy, oraz że istnieje ryzyko zinstrumentalizowania Kościoła po zakończeniu posługi prymasowskiej przez kard. Wyszyńskiego. Ordynariusz przemyski wskazywał nawet, że sekretarz Episkopatu miałby działać na korzyść władz komunistycznych. W przekonaniu bp. Tokarczuka Kościół powinien przyjąć aktywniejsza postawę i wesprzeć opozycję, która działała na rzecz poszerzenia społecznej wolności ${ }^{19}$. Ordynariusz przemyski ują to w swoim liście w następujący sposób: „Kościół dziesiątki lat walczył samotnie o wolność religijna i obywatelska, a Jego Prymas nie wahał się pójść do więzienia, dzięki czemu mimo nacisków i prześladowań nie tylko wytrwał, ale i zwyciężył, ratując nie tylko siebie, ale ducha całego Narodu. A czyż obecnie kiedy budzi się inteligencja /będąca do niedawna filarem marksizmu/, młodzież akademicka, robotnicy, chłopi i wszyscy skupiają się wokół tych samych dążeń i walki o poszanowanie praw ludzkich i obywatelskich, Kościół w Polsce miałby być sojusznikiem ateistycznego reżimu, który zresztą z różnych przyczyn jest $\mathrm{w}$ tej chwili bardzo słaby i niedołężny? Gdyby to się stało podeptalibyśmy nie tylko własna chlubna przeszłość, ale wykopalibyśmy zgubna przeszłość między sobą a Narodem; popełnilibyśmy największy błąd, ani do darowania, ani do naprawienia w przyszłości. Dlatego Ojciec Święty tak dobitnie i z tak mocnym akcentem ostrzegał nas w Częstochowie przed niebezpieczeństwem wmanewrowania i zinstrumentalizowania ze strony wojującego ateizmu. A przecież dzisiaj łatwiej utrzymać właściwy kierunek niż dawniej, bo nie jesteśmy sami, a przeciwnik przeżywa co raz więcej trudności. Jest to linia jedynie słuszna i zgodna zarówno z duchem Ewangelii, jak i dobrem Narodu. Wiem jakie zarzuty moga być $\mathrm{w}$ tej chwili postawione pod adresem mojego rozumowania - rozpolitykowanie, awanturnictwo, niebezpieczeństwo ingerencji ZSRR itp. Odpowiem na to krótko. Uważam, że skala możliwości między tzw. awanturnictwem, a duchowym kapitulanctwem jest obecnie mimo wszystko dość duża, większa nawet dziś niż jeszcze 3-4 lata".

Tego typu podejście wynikało poniekąd z charakteru ordynariusza przemyskiego, który był człowiekiem upartym, bezkompromisowym i twardo prezentującym swoje stanowisko. Bardzo dobrze jego osobowość scharakteryzował ks. Adam Boniecki, który podkreślał: „Bp. Tokarczuk był introwertykiem, człowiekiem, który dużo myślał nad tym, co czyni, nad swoją wizją i strategia. Nie improwizował, działał planowo. Był człowiekiem upartym, w sprawach istotnych bezkompromisowym. Docierały do niego argumenty, ale miał swoja wizję, swoją interpretację świata, wiedział swoje. Był człowiekiem głęboko religijnym i pobożnym «z chłopską cierpliwością wypełniał misję, której się

${ }_{19}$ Po latach pisał, że zarzucił w swoim liście bp. Dąbrowskiemu, że zależy mu na „jak najbardziej pozytywnym przedstawianiu władz i ich postępowania”. I. Tokarczuk, W służbie Kościoła i Narodu, Marki-Struga 1997, s. 100-101; A. Garbarz, op. cit., s. 376-377. 
podjąı" ${ }^{20}$. Wspomnianą charakterystykę bardzo dobrze uzupełnia relacja ks. Stanisława Janusza: „Bp Tokarczuk swa powaga, spokojem, oględnościa $\mathrm{w}$ wypowiedział stwarzał pewien dystans. W życiu codziennym czynił też niekiedy wrażenie człowieka małomównego. Nie to jednak stanowiło jądro jego oryginalności. Według nie tego typu powierzchowność wynikała z jego charakteru i osobowości. Był człowiekiem o temperamencie klasycznego choleryka połączonego z sangwinikiem. Żył idea. Codzienna miałkość go nie interesowała, głupstwami się nie zajmował. Nie potrafił rozmawiać o przysłowiowej pogodzie. Rozmowy z nim były rzeczowe, na wysokim poziomie intelektualnym. Szczególnie umiłowanym dla niego tematem była budowa świątyń i komunistyczne oszustwo. Tutaj był nieugięty i bezkompromisowy. W myśli głęboki, a w działaniu skuteczny"21. Wydaje się, że to właśnie cechy charakteru ordynariusza przemyskiego wpłynęły nie tylko na treść listu, ale również stylistykę jego argumentacji, którą można by nazwać nawet oskarżycielską.

Odpowiedź sekretarza Episkopatu jest utrzymana w zupełnie innym tonie, choć niewątpliwie bp Dąbrowski czuł się dotknięty niesprawiedliwymi w jego przekonaniu zarzutami wysuniętymi przez ordynariusza przemyskiego. Odpowiadał na nie jednak w spokojny sposób, wskazując na nielogiczność i niekonsekwencje zawarte w liście ordynariusza przemyskiego. Dodawał ponadto, że bp Tokarczuk jako jedyny z biskupów diecezjalnych nie rozmawia z nim jako sekretarzem Episkopatu na temat problemów z władzami w swojej diecezji. Biskup Dąbrowski zwracał również uwagę adresatowi listu, że swoje działania prowadzi w pełnym porozumieniu z prymasem Wyszyńskim: „Z Księdzem Prymasem, jako Przewodniczacym Konferencji Episkopatu, kontaktuję się prawie na co dzień. Nie mam przed nim żadnych tajemnic, każdą rozmowę przeprowadzoną z władzami państwowymi relacjonuję mu szczegółowo, często na piśmie. Przed ważniejszą rozmową uzgadniam stanowisko. Niczego też nie ukrywam przed Biskupami. Relacjonuję na Konferencjach Plenarnych wyniki rozmów, inicjatywy Sekretariatu, trudności, niepowodzenia i osiagnięcia. Być może, że nieraz z braku czasu relacje są zbyt krótkie. Wielu Biskupów bardzo interesuje się prowadzonymi z władzami rozmowami, szczególnie gdy dotycza ich diecezji. Przeprowadzają także z sekretarzem Episkopatu merytoryczne rozmowy, jak rozwiązywać sytuacje konfliktowe z władzami. Tylko Biskup Przemyski nie życzy sobie, aby sekretarz Episkopatu wtrącał się w Jego sprawy”. Biskup Dąbrowski w dalszej części swojego listu zwracał również uwagę, że nie tylko ordynariusz przemyski potrafi analizować rzeczywistość państwa komunistycznego oraz że jego nietykalność jako biskupa wynika

${ }^{20}$ Relacja ks. Adama Bonieckiego, w: Non omnis moriar..., s. 54.

${ }^{21}$ Relacja ks. Stanisława Janusza, w: Non omnis moriar..., s. 165. Choć równocześnie, jak wspominała Wanda Półtawska, w czasie rozmów był bardzo serdeczny. Relacja Wandy Półtawskiej, w: Non omnis moriar..., s. 307. 
z poparcia Episkopatu Polski: „Można tylko dodać, że Biskup Przemyski nie byłby nietykalny, gdyby za nim nie stał cały Episkopat Polski z jego wielkim Prymasem na czele, który już niejeden mocny list napisał w jego obronie".

Nie znamy dalszego rozwoju sytuacji, jeśli chodzi o relacje bp Tokarczuk - bp Dąbrowski. W dokumentacji Episkopatu Polski nie odnalazłem żadnego odniesienia do prezentowanej w tym miejscu wymiany korespondencji. W moim przekonaniu można jednak przypuszczać, że antagonistów pogodził kard. Wyszyński, który uważał, że dalsze eksponowanie różnic między ordynariuszem przemyskim a bp. Dąbrowskim moga wykorzystać władze PRL do próby skłócenia całego Episkopatu Polski. Wydaje się jednak, że jednym z efektów (choć odsuniętym w czasie) wymiany korespondencji, jaka miała miejsce w 1979 r., było zniesienie monopolu bp. Dąbrowskiego na kontakty z władzami. Lista rozmówców dygnitarzy partyjnych ze strony kościelnej znacząco się poszerzyła we wrześniu 1980 r. Dołączyli do nich metropolita krakowski kard. Franciszek Macharski, metropolita poznański abp Jerzy Stroba i ordynariusz gdański bp Lech Kaczmarek jako członkowie reaktywowanej wtedy Komisji Wspólnej przedstawicieli rządu i Episkopatu Polski² ${ }^{22}$.

Rafał Łatka

Warszawa

${ }_{22}$ K. Michalski, Działalność Komisji Wspólnej przedstawicieli Rzqdu PRL i Episkopatu Polski 1980-1989, Warszawa 2012, s. 79-85; R. Łatka, Obraz opozycji w czasie rozmów Komisji Wspólnej Przedstawicieli Rzqdu PRL i Episkopatu Polski w latach 1980-1983, w: Miejsce $i$ rola opozycji $w$ systemach autorytarnych i demokratycznych, red. K. Kowalik, M. Kluzik, Kraków 2013, s. 43-46. 


\title{
Dokument nr 1
}

\section{List bp. Ignacego Tokarczuka ordynariusza przemyskiego do bp. Bronisława Dąbrowskiego sekretarza Episkopatu Polski z 30 VII 1979 r. ${ }^{23}$}

\author{
Ekscelencjo \\ Najdostojniejszy Księże Biskupie, \\ Sekretarzu Episkopatu Polski,
}

Dziękuję za list, za „pro memoria” i ustne informacje przekazane za pośrednictwem ks. Majchra ${ }^{24}$.

W odpowiedzi postaram się wyjaśnić moje stanowisko, przedstawić mój punkt widzenia i ustosunkować się do konkretnych propozycji. Aby tego dokonać, konieczna jest rzeczą przedstawienie szerszego tła, tym bardziej, że rozpętana na mnie nagonka $\mathrm{w}$ drugiej połowie lipca jest czymś sztucznym, nie mającym $\mathrm{w}$ tym czasie żadnego chronologicznego, ani przyczynowego powiązania $\mathrm{z}$ sytuacja $\mathrm{w}$ diecezji.

Poświęcenie kaplicy w Przemyślu miało miejsce jeszcze 8 kwietnia, a w Tarnobrzegu 27 maja, natomiast odebranie nawy bocznej w kościele popijarskim w Rzeszowie /o czym dowiedziałem się dopiero po powrocie ze spotkania z Ojcem św. w Częstochowie/ 3 czerwca $^{25}$. Od tego czasu wierni w Przemyślu i Tarnobrzegu wznieśli już nowe świątynie, których wartość przewyższa milionowe sumy, przy czym prace były prowadzone jawnie, bez przeszkód z czyje[j]kolwiek strony. I naraz w lipcu /dopiero/ wybucha sztucznie rozpętana kampania; zreszta nie pierwszy raz. Pamięta Ekscelencja sprawę zmiany nazw geograficznych na terenie diecezji, czy choćby historię byłej

${ }^{23}$ Pozostawiono oryginalną budowę akapitów. Podkreśleń na obu prezentowanych dokumentach dokonał prawdopodobnie osobiście prymas Stefan Wyszyński. Można tak wnioskować z faktu, że źródła pochodzą z dokumentacji Sekretariatu Prymasa Polski znajdującej się w Archiwum Archidiecezji Warszawskiej w spuściźnie po kard. Wyszyńskim.

${ }^{24}$ Ksiądz Zdzisław Majcher (1929-2012), kapłan archidiecezji przemyskiej, notariusz kurii biskupiej w Przemyślu (1958-1972), jej wicekanclerz (1972-1977) i do 1992 r. kanclerz. Dane biograficzne za: G. Polak, Kto jest kim w Kościele katolickim, Warszawa 1996, s. 220-221; Non omnis moriar..., s. 47.

${ }^{25}$ Wykaz kościołów wybudowanych dzięki staraniom abp. Tokarczuka zob. I. Tokarczuk, Z przemyskiej „twierdzy”..., t. II, s. 189-218; idem, Kochałem tych ludzi..., s. 184-247. 
cerkwi w Jureczkowej. Ile fałszu i kłamstwa wyprodukowano tylko po to, aby mnie oczernić i wywrzeć na mnie nacisk.

Obecnie dzieje się to samo. Dlatego tych zjawisk nie da się wytłumaczyć bez uchwycenia głębszego problemu, który się za tym wszystkim kryje. Tu bowiem, nie chodzi o jedna, czy drugą świątynię, bo cóż to jest dla państwa: natomiast gra idzie o coś bardzo istotnego, mianowicie o linie polskiego Episkopatu na przyszłość. Tak jak wszystko na świecie, tak samo i wielka epoka polskiego Kościoła pod przewodnictwem Ks. Prymasa zbliża się niestety do końca. Żałujemy, że tak jest, ale wszyscy jesteśmy bezradni wobec praw życia.

Przepraszam, że o tym piszę, ale jest to konieczne dla zrozumienia dalszego toku moich wywodów.

Władze doskonale o tym wiedzą i dlatego z myślą o przyszłości snują swoje plany, które nietrudno odczytać z różnych ich pociagnięć. Dążeniem partii jest ustawić cały Episkopat, aby był w jakimś sensie podpora jej rządów w kraju /tak jak się to stało na Węgrzech/ w imię rzekomej jedności narodowej; wspólnej pracy dla celów nadrzędnych, odnowy moralnej itp. Za tymi pięknie brzmiącymi hasłami kryje się ustawiczne dążenie, aby Kościół polski tak wmanewrować i zinstrumentalizować, żeby był narzędziem dla polityki władz. W minionym okresie nie udało się, a teraz odpowiednie czynniki maja nadzieję, że to się uda, z czym zresztą na poufnych zebraniach partyjnych wcale się nie kryją. Przez takie wmanewrowanie Episkopatu partia nie tylko wzbogaciłaby się o nowy instrument swej polityki, ale osiagnęłaby znacznie większe korzyści. Osłabiałby cały front narodowy przez wbicie klina nieufności między Kościół, a inteligencja, młodzież akademicką i wszystkie świadomie myślące grupy społeczne, co w samym aspekcie pastoralnym byłoby błędem o strasznych skutkach, nie wspominając już o innych. Można by nawet powiedzieć, że takie rozwiązanie w obecnej sytuacji świadczyłoby o jakiejś bardzo tragicznej ślepocie. Kościół dziesiątki lat walczył samotnie o wolność religijna i obywatelska, a Jego Prymas nie wahał się pójść do więzienia, dzięki czemu mimo nacisków i prześladowań ${ }^{26}$ nie tylko wytrwał, ale i zwyciężył, ratując nie tylko siebie, ale ducha całego Narodu. A czyż obecnie kiedy budzi się inteligencja /będąca do niedawna filarem marksizmu/, młodzież akademicka, robotnicy, chłopi i wszyscy skupiają się wokół tych samych dążeń i walki o poszanowanie praw ludzkich i obywatelskich, Kościół w Polsce miałby być sojusznikiem ateistycznego reżimu, który zresztą z różnych przyczyn jest w tej chwili bardzo słaby i niedołężny? Gdyby to się stało, podeptalibyśmy nie tylko własną chlubna przeszłość, ale wykopalibyśmy zgubna przeszłość między sobą, a Narodem; popełnilibyśmy największy błąd, ani do darowania, ani do naprawienia w przyszłości. Dlatego Ojciec Święty tak dobitnie i z tak

${ }^{26}$ Od słowa: „prześladowań” do słów: „a Narodem” pociagnięta została z boku niebieska linia, co prawdopodobnie świadczy o tym, że prymas Wyszyński traktował ten fragment listu jako szczególnie istotny. 
mocnym akcentem ostrzegał nas w Częstochowie przed niebezpieczeństwem wmanewrowania i zinstrumentalizowania ze strony wojujacego ateizmu ${ }^{27}$. A przecież dzisiaj łatwiej utrzymać właściwy kierunek niż dawniej, bo nie jesteśmy sami, a przeciwnik przeżywa co raz więcej trudności. Jest to linia jedynie słuszna i zgodna zarówno z duchem Ewangelii, jak i dobrem Narodu.

Wiem, jakie zarzuty moga być w tej chwili postawione pod adresem mojego rozumowania - rozpolitykowanie, awanturnictwo, niebezpieczeństwo ingerencji ZSRR itp. Odpowiem na to krótko. Uważam, że skala możliwości między tzw. awanturnictwem, a duchowym kapitulanctwem jest obecnie mimo wszystko dość duża, większa nawet dziś niż jeszcze 3-4 lata.

Tu dochodzę do sedna sprawy. Partia uważa, że obecnie największą przeszkodą w kalkulacjach na przyszłość jest biskup przemyski, stąd nieustanne ataki, zarzuty, próby wyizolowania trwające już od szeregu lat ${ }^{28}$. Próbuje użyć do tego celu nawet ludzi Kościoła. Pamięta Ekscelencja posiedzenia Rady Głównej w Choszczówce ${ }^{29}$, naciski ze strony Poggi-ego ${ }^{30}$, który powoływał się w rozmowie ze mna między innymi i na Ks. Bpa. Sekretarza, kilkukrotnie publiczne wypowiedzi Ekscelencji wobec Episkopatu zmierzajace do nacisku na mnie, referujac to co mówił Kakol ${ }^{31}$, czy Kania ${ }^{32}$, a nigdy nie słyszałem, co na to rozmówcom partyjnym odpowiedział Biskup Sekretarz.

Proszę mnie źle nie zrozumieć, nie piszę tego ani z żalem, ani z pretensjami, wspominam tylko po to, aby pokazać cały mechanizm działania.

Ja osobiście - przyznam się szczerze - wolałbym cichą i spokojną pracę, nie szukam walki zaczepnej. Ale jako człowiek, Polak i biskup muszę stanąć, gdy zachodzi potrzeba, w obronie wyższych wartości. Kieruję się w tym wszystkim trzema następującymi wytycznymi:

1/ Własne sumienie, któremu pragnę być posłuszny,

27 Słowa: „wmanewrowania i zinstrumentalizowania ze strony wojujaccego ateizmu” zostały podkreślone na niebiesko.

28 Słowa: „obecnie największą przeszkodą w kalkulacjach na przyszłość jest biskup przemyski, stąd nieustanne ataki, zarzuty, próby wyizolowania trwające już od szeregu lat” zostały podkreślone na niebiesko.

${ }^{29}$ Chodzi o posiedzenie Rady Głównej Episkopatu z 2 X 1978 r.

${ }^{30}$ Luigi Poggi (1917-2010), włoski duchowny, watykański dyplomata, od 1973 r. odpowiadał za dialog z państwami bloku wschodniego, zaś od 1975 r. kierował delegacją ds. kontaktów roboczych z PRL, w 1994 podniesiony do godności kardynalskiej. Członkowie Rady Głównej Episkopatu Polski uważali w 1979 r., że należy go odwołać ze stanowiska osoby odpowiedzialnej za nawiązanie stosunków dyplomatycznych Stolica Apostolska - PRL. Na ten temat szerzej zob. R. Łatka, Rada Główna Episkopatu Polski a pierwsza pielgrzymka Jana Pawła II do Ojczyzny w 1979 r., „Dzieje Najnowsze” 2018, nr 1, s. 229-262.

${ }^{31}$ Kazimierz Kąkol (1920-2016), publicysta, polityk, nauczyciel akademicki, w latach 1974-1980 minister-kierownik UdsW.

${ }^{32}$ Stanisław Kania (ur. 1927), polski działacz komunistyczny, poseł na Sejm PRL w latach 1972-1989, 1971-1980 sekretarz KC PZPR odpowiedzialny za nadzór nad MON i MSW, 1980-1981 I sekretarz KC PZPR. 
2/ Dobro Kościoła i Narodu,

3/ Obowiązki Biskupa.

Moja droga wierności tym zasadom nie jest ani wygodna ani łatwa, ale Bóg domaga się, abym nią mimo wszystko, obojętnie ile by to kosztowało, szedł aż do końca. Zreszta już przy nominacji na ordynariusza diecezji przemyskiej powiedziano mi, aby[m] był gotów w razie potrzeby nawet cierpieć za wiarę. Jestem zwykłym, słabym człowiekiem, nie szukam swojej chwały, ale ufam, że Bóg mi dopomoże zdać mój egzamin życiowy, tak jak On sobie życzy. Dlatego przyjmując sakrę biskupią nie wykluczałem nigdy tej możliwości, że może nawet przyjdzie cierpieć dla sprawy Bożej. W duchu znosiłem i znoszę wszystkie kampanie przeciw mnie i wszelkie naciski, obojetnie z czyjej strony pochodziły.

Przed 13 laty, kiedy broniłem kościoła w Wołkowyi ${ }^{33}$, były wojewoda rzeszowski p. E. Duda ${ }^{34}$ powiedział mi, że stwarzam konflikty z państwem, które wyciagnie konsekwencje w stosunku do mnie. Zapytałem ,jakie”? Kiedy na to pytanie nie odpowiedział sam dodałem: „wy mnie możecie zaaresztować i zabić, nic więcej, ale przyjmijcie do wiadomości, że są wartości, których nie odstapię nawet za tę cenę". To samo mogę powtórzyć dzisiaj - jestem gotów na wszystko. Nie szukam awantur, ani zwad, ale stoję wiernie przy boku Ludu chrześcijańskiego, który walczy o swoje prawa, świątynie i zdrowe życie rodzinne i narodowe. Ja stoję przy Ludzie, a on widząc we mnie słabego, ale pełnego dobrej woli pasterza, stoi przy mnie. Uważam, że innego stanowiska biskup katolicki nie może zająć nigdy, a tym bardziej w naszych czasach.

A teraz przejdę do zagadnień szczegółowych.

1/ Propozycja „wycofania się z budynków nielegalnie zajętych” jest nierealna $\mathrm{z}$ wielu względów.

a/ nie sa to budynki nielegalnie zajęte. Parcele i budynki w Przemyślu i Tarnobrzegu zostały zakupione $u$ ich dotychczasowych legalnych właścicieli. Nawa boczna kościoła popijarowskiego w Rzeszowie przyznana została kościołowi przez sąd powiatowy w Rzeszowie jeszcze w 1959 r.

b/ wierni wnieśli w Przemyślu i Tarnobrzegu nowe budynki sakralne, kosztowało ich to wiele pracy i pieniedzy. Zrobili to sami, dobrowolnie, dla siebie i dla swoich dzieci. Dawno już występowali z propozycjami stworzenia tam świątyń, w odpowiedzi na co Kuria zwracała się do władz z prośba o pozwolenie na budowę, ale to wszystko było bezskuteczne. Cierpliwość ludzka ma swoje granice. Kiedy wierni znajda parcele, kupują i następnie buduja to co ma biskup robić? Zakazywać i odpychać od Kościoła?

${ }^{33}$ Chodzi o konflikt związany z żądaniem władz wojewódzkich, by bp Tokarczuk przeniósł parafię z Wołkowyi do Polańczyka lub Górzanki. Na ten temat szerzej zob. I. Tokarczuk, Kochatem tych ludzi..., s. 178-183.

${ }^{34}$ Mowa o Edwardzie Dudzie, przewodniczącym Wojewódzkiej Rady Narodowej w Rzeszowie w okresie 30 III 1965 - 22 IV 1969. Dane biograficzne za: ibidem, s. 178. 
c/ nie mam żadnego prawa dysponowania tymi światyniami, których właścicielami sa dane wspólnoty. Dlatego władze chca, aby te świątynie lud opuścił, niech zwracaja sie do ich właścicieli, bo oni dawali swoje grosze i oni budowali, nie dla biskupa, czy danego kapłana, a dla siebie,

d/ Ekscelencja może to wszystko sprawdzić na miejscu, o co nawet bardzo proszę, żeby nie wydawało się czasem, że przedstawiam sytuację trochę spreparowana.

2. Druga propozycja brzmi „Proszę Kurię Diecezjalna, aby dla dobra stosunków Kościół-Państwo rozważyła tą propozycję i udzieliła odpowiedzi jak najprędzej tut. Sekretariatowi”. Otóż Kuria rozważyła i daję odpowiedź jak w p.l. [tak w oryginale].

W samej tego rodzaju propozycji złożonej do Kurii mieści się założenie, że przyczyna niepokojów i psucia stosunków Kościół-Państwo jest właśnie Kuria, konkretniej Biskup. W tym mieści się cała przewrotność i chytrość marksistowskiej dialektyki. Nie Kuria, nie Biskup są winni, że psują się czasem stosunki Kościół-Państwo, ale system, który daży do zniszczenia religii poprzez kolejne etapy jej opanowania i zinstrumentalizowania. Biskup tylko broni religii i jej praw, a razem z nia człowieka. Ustępstwo tutaj /faktyczne niemożliwe jak w p.l/ nie byłoby krokiem do pokoju, ale do stawiania dalszych żądań. Zna z pewnością Ekscelencja bajkę Kryłowa o owcy i wilku. Wilk zarzuca owcy brak nastawienia pokojowego, awanturnictwo, bo nie daje się spokojnie pożreć. Tak jest dosłownie i w naszej omawianej sytuacji. Jeśli władze chcą rzeczywiście pokoju i dobrych stosunków Kościół-Państwo, niech zaprzestana walki z religią we wszelkiej postaci. Od władz zależy pokój i dobre stosunki Kościół-Państwo, a nie od biskupa przemyskiego. Zreszta biskup nie jest od tego, żeby pomagał władzom ograniczać i niszczyć religię.

3. Aby okazać dobrą wolę, mogę wysunacć jedną propozycję na przyszłość. Jeśli władze zagwarantował[y]by w ściśle określonym czasie /niezbyt odległym, bo ludzie nie mają cierpliwości zbyt długo czekaćl, że pozwolą na budowę kościoła w nowym osiedlu, wtedy ja zobowiązałbym się do tego, aby ludzi prosić i im tłumaczyć, żeby z budowa zaczekali aż do otrzymania pozwolenia. Warunkiem nieodzownym jest zobowiązanie na piśmie i dotrzymanie obietnicy, by w przeciwnym razie ani władze, ani ja nie miałbym żadnego zaufania $u$ wiernych na przyszłość.

W związku z tą całą „burzą" nasuwa mi się na myśl cały szereg innych uwag, które - jak mi się wydaje - powinien dla dobra sprawy tutaj wyłuszczyć.

Pomijam cały problem aresztowania mnie, co może być tylko metoda zastraszania, względnie faktycznym zamiarem. Odniosłem wrażenie, że Ekscelencja przyjmuje ta druga możliwość. Moje stanowisko co do takiej ewentualności jasno już określiłem, natomiast pozostaje pytanie bardziej zasadnicze, a mianowicie jakie stanowisko powinien zając Sekretarz Episkopatu „poufnie” wtajemniczony w te zamiary władz. Czy ma razem z władzami naciskać na delikwenta, aby przymusić do niemoralnych w tym wypadku kompromisów, 
czy raczej dodawać mu siły i odwagi, aby zachował sie jak należy. Tym bardziej, że żadnej szkody Kościołowi ani Narodowi nie wyrządziłem. Blisko 200 kościołów odzyskanych i nowo wybudowanych, zorganizowane około 130 parafii ${ }^{35}$, uwolnienie kapłanów od zależności od państwa, dzięki czemu nie muszą niczego ślubować i nikt ich nie segreguje; stworzenie gęstej sieci dobrych punktów katechetycznych, w których cała katolicka młodzież szkół podstawowych ma w tygodniu 2 lekcje religii, dostosowanie organizacyjne parafii i diecezji do nowych warunków społeczeństwa uprzemysłowionego i zurbanizowanego, oto dorobek diecezji w ostatnich latach. Wskutek tego diecezja położona na kresach południowo-wschodnich stanowi zintegrowany i silny bastion polskości i katolicyzmu.

To jest moja wina. Z tonu „pro memoria” wynika, że Ekscelencja wybrał pierwsza droge, uległ naciskowi swoich wysokich rozmówców ${ }^{36}$. Do takiego stwierdzenia upoważnia mnie także cały szereg innych faktów, które obserwuje /nie tylko ja/ od dłuższego czasu, a które rzutuja bardzo na cała atmosfere stosunków Kościól-Państwo w jeszcze szerszym zakresie niż mój casus.

1. Stosunek do całej akcji p. Zabłockiego ${ }^{37}$, którego rola dziś już nawet nie może podlegać dyskusji, jest jednoznacznie jasna.

2. Stosunek do PAX-u. Widzimy wszyscy /używam I osoby liczby mnogiej dlatego, że wielu biskupów w rozmowie ze mna ma te same obawy i wątpliwości/ wyraźna zmianę linii bez podania racji. /Może te racje sa, chętnie byśmy wysłuchali/. A przecież w powszechnym odczuciu społeczeństwa PAX w niczym nie zmienił swoich celów, ani sposobów działania ${ }^{38}$.

3. Kilkakrotnie wypowiedzi Ekscelencji na Radzie Głównej i Plenum Episkopatu pod adresem ruchów demokratycznych w Polsce ${ }^{39}$. Załatwienie sprawy sloganem - żydomasonerii - jest wielkim uproszczeniem - delikatnie mówiąc - bardzo poważnej sprawy.

4. Jednostronne zaufanie do wypowiedzi i zapewnień p. Gierka ${ }^{40}$.

Nie chcę go sądzić jako człowieka, ale jedno wiemy wszyscy, że w obecnym systemie jest tylko śrubka, trochę większą niż inne, ale poza tym tylko

${ }^{35}$ Dzięki staraniom bp. Tokarczuka w latach 1966-1993 wzniesiono w sumie ponad 400 kościołów w diecezji przemyskiej. M. Krzysztofiński, op. cit., s. 10.

${ }^{36}$ Biskup Tokarczuk ma na myśli wicepremiera Jaroszewicza i Kazimierza Kąkola, ministra UdsW.

${ }^{37}$ Janusz Zabłocki (1926-2014), publicysta, polityk, działacz katolicki, poseł na Sejm PRL IV, V, VI, VII i VIII kadencji, założyciel i przewodniczący Polskiego Związku Katolicko-Społecznego.

${ }^{38}$ W 1979 r. zmarł Bolesław Piasecki, jego następcą na stanowisku przewodniczącego PAX został Ryszard Reiff, którego przyjął na audiencji w 1979 r. prymas Wyszyński.

39 Biskup Dąbrowski kilkukrotnie zajmował w latach 1976-1979 krytyczne stanowisko wobec aktywności opozycji przedsierpniowej. Na ten temat szerzej zob. R. Łatka, Rada Gtówna Episkopatu..., s. 117-118.

${ }^{40}$ Edward Gierek (1913-2001), polski działacz komunistyczny, w latach 1970-1980 I sekretarz KC PZPR. 
śrubka. Podjęta ostatnio gloryfikacja Bieruta ${ }^{41}$ i odsłanianie na jego cześć pomnika ${ }^{42}$ potwierdza $\mathrm{w}$ pełni moją tezę. System jest wciąż wrogi religii, cel strategiczny został ten sam przy pewnej zmianie taktyki. Na miejsce metod graniczacych z terrorem przyszły umizgi, kwiaty, powitania na lotnisku, ciepłe słówka, a wszystko w tym celu, aby łatwiej swoje osiagnąć. Wydaje mi się, że na metody bardziej brutalne byliśmy trochę odporniejsi niż na wyszukane sztucznie grzeczności, które zasłaniaja nam pełne poczucie rzeczywistości. Czyż nie po tej linii szła relacja Ekscelencji w czasie ostatniego posiedzenia Rady Głównej, że tylko w kilku diecezjach były pewne przeszkody w zwiazku z pielgrzymkami na spotkanie z Ojcem św., natomiast w innych było wszystko w porzadku ${ }^{43}$ /podał Ekscelencja nawet dokładną ilość tych diecezji/. Tymczasem dostarczone materiały i dyskusja pokazały co innego. Czuło się, że Ekscelencji bardzo zależy na jak najbardziej pozytywnym przedstawieniu władz i ich postepowania. Nikt nie chce nikogo bezpodstawnie potępiać, ale bądźmy obiektywni.

A czy projekty końcowego komunikatu z dwóch w ostatnim czasie odbytych posiedzeń Plenum Episkopatu nie szły po tej samej linii, próbujacej wciagnać Episkopat w rydwan polityki partii. Olbrzymia większość członków posiedzenia odrzuciła ten projekt, bo wszyscy oni czuli, że ta droga do niczego dobrego nie prowadzi.

To wszystko budzi niepokój i to wielu biskupów. Nie piszę tego wszystkiego po to, żeby sprawić Ekscelencji przykrość, ale żeby Ekscelencja uświadomił sobie w pełni, jaka jest sytuacja.

Wiem dobrze, jak bardzo trudna jest pozycja Ekscelencji jako Sekretarza Episkopatu na odcinku kontaktu z władzami. Tamta strona używa wszystkich bardzo bogatych sposobów wpływania i naciskania na Ekscelencję bezpośrednio lub pośrednio przy pomocy różnych środowisk i osób, sam nie raz tego doświadczyłem na sobie. Dlatego uważam, że zarówno dla dobra osobistego, jak i dobra sprawy byłoby rzeczą pożyteczną oprzeć się na szerszej opinii Episkopatu, nie bać się wszechstronnie przedyskutować /i to nie raz/ na nowo nie tylko całokształt stosunków Kościół-Państwo, ale problemy szczegółowe jak Neoznak ${ }^{44}$, PAX, taktyka p. Gierka, metody Kąkola itd. Takie

${ }^{41}$ Bolesław Bierut (1892-1956), polski działacz komunistyczny, od 1947 r. prezydent RP, przywódca PZPR w latach 1948-1956.

${ }^{42}$ Pomnik ku czci Bolesława Bieruta odsłonięto 19 VII 1979 w Lublinie, na uroczystość związaną z obchodami 35. rocznicy PRL przybył osobiście Edward Gierek.

${ }^{43}$ Mimo zapewnień władz centralnych na poziomie wojewódzkim prowadzono działania zmierzajace do ograniczenia zasięgu pielgrzymki Jana Pawła II. O efektach pielgrzymki i utrudnieniach stosowanych przez władze dyskutowano w czasie posiedzeń Rady Głównej Episkopatu z 26 VI i 4 IX 1979 r. Zob. R. Łatka, Rada Gtówna Episkopatu...

${ }^{44}$ Chodzi o grupe posłów katolickich, która weszła do Sejmu PRL w 1976 r. w wyniku rozłamu w środowisku „Znak”. Powodem rozłamu był konflikt dotyczący nowelizacji konstytucji PRL i wpisania do niej kierowniczej roli partii. Na jego skutek do Sejmu w 1976 r. weszli tylko ci działacze, którzy podporządkowali się tej decyzji władz PRL. Z tego powodu 
szersze i głębsze rozpatrzenie wielu spraw da lepsze oparcie dla Ekscelencji w rozmowach z władzami, będzie stanowić skuteczna przeciwwage dla ich nacisków, a równocześnie będzie pogłębiać nasze wzajemne zaufanie, które jest warunkiem jedności.

Wtedy także może się pokazać, że pewne oceny /w tym przypadku moje/ sa częściowo lub całkowicie niesłuszne, nie wszystkie elementy sytuacji były znane, nikt tego nie powiedział. Wszyscy ponosimy odpowiedzialność za Kościół i chcemy to robić przy pełnej znajomości stanu rzeczy, a nie na ślepo. Jeśli nie na Konferencji Plenarnej da się wszystko omówić, to konieczne to jest przynajmniej w gronie Rady Głównej.

Jeszcze jedna myśl: Ekscelencja nie może w tym przypadku zasłaniać się kimś innym /np. ks. Prymasem/. Ekscelencja ma bardzo dużo samodzielności, a Eminencja choćby ze względu na nawał obowiazków nie wszystko może w danej chwili znać. Dlatego - powtarzam - od Sekretarza Episkopatu bardzo dużo zależy.

Tymi uwagami kończę i tak już długi list. Traktowałem go jako swobodna i szczera wymianę myśli zatroskany naszymi wspólnymi sprawami, i tak go proszę traktować. Nie mam pretensji w żadnym wypadku do nieomylności czy monopolu prawdy, gotów jestem posłuchać każdej opinii popartej argumentami. Nie chciałem w niczym sprawić Ekscelencji przykrości, bo dobrze wiem, co to znaczy, bo sam ich doznaję, a jeśli w czymś dotknąłem niesłusznie to przepraszam. Kierowałem się tylko zasada clara faciunt amicos ${ }^{45}$.

Proszę przyjąć wyrazy głębokiej czci i oddania w Panu.

x. Ignacy Tokarczuk ${ }^{46}$

PS. Wszystkie teksty moich homilii mam ${ }^{47}$.

założyciele koła poselskiego „Znak” nazywali wspomnianą reprezentację katolików świeckich „neoznakiem”. Na ten temat szerzej zob. A. Friszke, Koło postów „Znak” w Sejmie PRL 1957-1976, Warszawa 2002.

${ }^{45}$ Chodzi o rzymską zasadę łacińską: clara pacta claros faciunt amicos (,Jasne układy tworzą wiernych przyjaciół").

${ }^{46}$ Podpis odręczny.

${ }^{47}$ Post scriptum w całości wpisane ręcznie. 


\section{Dokument nr 2}

\section{List Sekretarza Episkopatu Polski bp. Bronisława Dąbrowskiego do bp. Ignacego Tokarczuka ordynariusza przemyskiego z 22 VIII 1979}

SEKRETARZ EPISKOPATU

POUFNE

Warszawa 22 sierpnia 1979

Ekscelencjo,

Przewielebny Księże Biskupie!

List Jego z dnia 30 lipca br. otrzymałem. Przeczytałem go uważnie i dokładnie.

Muszę stwierdzić, że wiele sformułowań w tym liście zawartych idzie zbyt daleko i nie dotyczy tylko mojej osoby, inne zaś nie odpowiadaja prawdzie, a nawet poddają w wątpliwość linię „polskiego episkopatu na przyszłośćc” /por. s. $2 /$.

Gdy idzie o mnie, to jestem świadom, że to co robię, robię może nieudolnie, nie moge jednak przyjać oskarżenia, że robie to przewrotnie i pomagam komunistom do zwalczania Kościoła oraz, że razem z delegatem Stolicy Apostolskiej Poggi'm daje się używać do nacisków na Biskupa Przemyskiego /por. str. 3/.

Ksiądz Biskup w swoim liście odwołuje się do własnego sumienia. Ja też mam sumienie i często je kontroluję, bo chce być przede wszystkim posłuszny woli Bożej. Kontroluję ponadto, działalność swoja, jako Sekretarza Episkopatu, w szczerych rozmowach z Ojcem Świętym, Jego Kuria, z Prymasem Polski, a także w rozmowach z Księżmi Biskupami, którzy nierzadko odwiedzaja Sekretariat Episkopatu. Z Księdzem Prymasem, jako Przewodniczacym Konferencji Episkopatu, kontaktuje sie prawie na co dzień. Nie mam przed nim żadnych tajemnic, każdą rozmowę przeprowadzoną z władzami państwowymi relacjonuję mu szczegółowo, często na piśmie. Przed ważniejszą rozmowa uzgadniam stanowisko. Niczego też nie ukrywam przed Biskupami. Relacjonuję na Konferencjach Plenarnych wyniki rozmów, inicjatywy Sekretariatu, trudności, niepowodzenia i osiagnięcia. Być może, że nieraz z braku czasu relacje sa zbyt krótkie ${ }^{48}$.

${ }^{48}$ Relacje i sprawozdanie z tych rozmów opublikował Peter Raina: Rozmowy z władzami PRL..., t. I-II. Znajduja się one również w zbiorach archidiecezji warszawskiej: AAW, SPP, 04/88-115, Sekretarz Episkopatu Polski. 
Wielu Biskupów bardzo interesuje się prowadzonymi z władzami rozmowami, szczególnie gdy dotyczą ich diecezji. Przeprowadzaja także z sekretarzem Episkopatu merytoryczne rozmowy, jak rozwiązywać sytuacje konfliktowe z władzami. Tylko Biskup Przemyski nie życzy sobie, aby sekretarz Episkopatu wtracał sie w Jego sprawy.

Nie jest zgodne z prawda stwierdzenie zawarte w liście, że „nigdy nie słyszałem co rozmówcom partyjnym odpowiedział Biskup Sekretarz". Protokoły, które referowałem na Radzie Głównej świadczą o czymś innym ${ }^{49}$. Ksiądz Biskup ma również odpisy zdecydowanych moich pism do władz w Jego obronie. Prawdą natomiast jest, że Ksiadz Biskup nie skwitował ich życzliwym słowem. Dlaczego? Dlatego chyba, że Ksiądz Biskup już sam fakt podjęcia rozmowy na Jego temat uważa za nacisk na Niego, a nawet utrzymuje, że „ulegam naciskowi swoich wysokich rozmówców” i pozwalam się im używać za narzędzie do rozsadzania jedności Episkopatu i do osłabiania Kościoła.

To przykre oskarżenie jest gołosłowne, a nawet złośliwe, musze zdecydowanie odrzucić, bo stawia moje morale kapłańskie pod znakiem zapytania. 30 już lat pod kierunkiem Księdza Prymasa służę Kościołowi w Polsce, hartowany przez 20 lat w szkole Biskupa Z. Choromańskiego ${ }^{50}$, a dziś w opinii Biskupa Przemyskiego znalazłem się w jednym szeregu $\mathrm{z}$ księżmi patriotami. To jest zbyt krzywdzace, dla mnie osobiście bardzo bolesne, tym bardziej że Ksiądz Biskup podpiera swoją opinię stwierdzeniem „wielu biskupów w rozmowie ze mna ma te same obawy i wątpliwości”/por. str. $6 \mathrm{nr} 2 /$.

Ufając Chrystusowi, który nazwał błogosławionymi pokój czyniących, postanowiłem nie odpłacać „pięknym za nadobne”, chociaż muszę przyznać nie łatwo mi to przychodzi, jako że to nie pierwszy atak bezpośredni - nie liczę tych z ukrycia - na moja osobę. Transeant! ${ }^{51}$

Szkoda tylko, że Księdza Biskupa poniósł temperament i napisał to, czego rozważny człowiek pisać nie powinien. Scripta manent $5^{52}$

Zamiast długiego wywodu ujawniającego Jego wewnętrzne napięcia, często nie a propos, odpowiedzia wystarczajaca na „pro memoria” z dnia 23 lipca br.

${ }^{49} \mathrm{Na}$ niemal każdym posiedzeniu Komisji/ Rady Głównej Episkopatu w latach 1970-1989 znajdował się punkt: relacja abp. Dąbrowskiego z rozmów z władzami, w której przedstawiał on ich efekty.

${ }^{50}$ Arcybiskup Dąbrowski czuł się uczniem bp. Choromańskiego, którego wspominał w następujący sposób: „Miał wysokie poczucie sprawiedliwości i jakiejś wrodzonej prawości. Dla nikogo nie był zagadka: co w myśli to na i na ustach. Zdolny i nieprzeciętny dyplomata na forum publicznym. Nigdy jednak w życiu osobistym nie kierował się dyplomacja. Był człowiekiem szlachetnym, człowiekiem, który w biskupstwie Chrystusowym z dnia na dzień wzbogacał swą osobowość. Kapłaństwo swoje i biskupstwo traktował sumiennie i głęboko tradycyjnie, dlatego wobec Boga był skrupulatnie wierny i dziecięco oddany”. B. Dąbrowski, Ecce Homo - ksztattowanie petnego człowieka w życiu zakonnym, w: „Instaurare omnia in Christo"..., s. 66.

51 „Pomijam”.

${ }^{52}$ „Napisane pozostaje”. 
byłaby część Jego listu z 30 lipca br. zaczynajaca się od słów „A teraz przejdę do zagadnień szczegółowych”/str. 49/, a kończąca się zdaniem „Warunkiem nieodzownym jest zobowiązanie na piśmie i dotrzymanie obietnicy, bo w przeciwnym razie ani władze ani ja nie miałbym żadnego zaufania u wiernych na przyszłość"/str. 5/.

$\mathrm{O}$ to mi chodziło i za to dziekuje. To stanowisko daje mi oparcie w rozmowach z władzami państwowymi, z którymi rozmawiam na wyraźne zlecenie Konferencji Episkopatu Polski.

Ocena tendencji i zamiarów ateistycznego systemu jest słuszna i rzeczowa, ale groteskowe jest przeświadczenie, że tylko Biskup Przemyski ja widzi i przed nia przestrzega.

Fałszywe wnioski wyciagnięte z oceny sytuacji skłaniaja Księdza Biskupa do podnoszenia przedwczesnych obaw o przyszłość Kościoła w Polsce, do stawiania znaku równania między „dążeniem partii” a Kościołem - „sojusznikiem ateistycznego reżimu" /!?/. W minionym okresie - pisze Ksiądz Biskup - nie udało się, a teraz odpowiednie czynniki mają nadzieję, że się uda...” Dalej Ksiadz Biskup uważa, że Episkopat Polski już znalazł się na pochylni i dlatego woła na alarm słowami „takie rozwiąanie w obecnej sytuacji świadczyłoby o jakiejś bardzo tragicznej ślepocie...” Kościół dziesiątki lat walczył samotnie o wolność religijną i obywatelską... a czyż obecnie... Kościół w Polsce musiałby być sojusznikiem ateistycznego reżimu... /str. 3/.

Po co to wszystko Ksiądz Biskup pisze? Dlaczego aż tak rozpaczliwy alarm? Czy po to, żeby powiedzieć, że wszystkiemu jest winien sekretarz Episkopatu, który „ma bardzo dużo samodzielności” i „nie może zasłaniać się kimś innym lnp. Księdzem Prymasem/", czy po to żeby sie z nim rozprawić? itd.

Gdybym odszedł ze stanowiska sekretarza Episkopatu, krzywda by mi się nie stała. Po 30 latach $^{53}$ trudnej służby Kościołowi powinien odejść na odpoczynek, choćby i zdyskryminowany. Mniejsza o powód. Nie sądy ludzkie, ale osąd Boskiego Sędziego jest decydujacy.

Tu jednak idzie o coś innego! Alarm trzeba było uczynić po to, ,aby dojść do sedna rzeczy”, tj. „Part[i]a uważa, że obecnie największa przeszkodą w jej kalkulacjach na przyszłość jest biskup przemyski"/str. 3/. Sapienti sat ${ }^{54}$. Można tylko dodać, że Biskup Przemyski nie byłby nietykalny, gdyby za nim nie stał cały Episkopat Polski z jego wielkim Prymasem na czele, który już niejeden mocny list napisał $\mathrm{w}$ jego obronie ${ }^{55}$.

$\mathrm{Na}$ tym kończę.

Co do innych zarzutów odpowiadam - gratis asseritour, gratis negatur ${ }^{56}$.

\footnotetext{
${ }^{53}$ Biskup Dąbrowski swoją pracę przy Episkopacie Polski rozpoczą w 1950 r.

${ }^{54}$ „Mądremu wystarczy”.

${ }^{55}$ Prymas Wyszyński przywiazywał wielką wagę do jedności Episkopatu i z tego również względu bronił każdego oskarżanego przez władze biskupa.

${ }^{56}$ „Wolno wyrazić, wolno zaprzeczyć”.
} 
Jeżeli Ksiądz Biskup będzie sobie życzył, albo na posiedzeniu Rady Głównej bedzie to potrzebne, ustosunkuje sie do każdego zarzutu z osobna, które albo oparte są na plotce, albo Ksiądz Biskup myśli o kimś innym, aby eufemicznie mówić o mnie, zamiast o osobach, do których zarzuty kieruję, może dlatego, że nie ma odwagi wyrazić swoich obaw wprost zainteresowanym?

Również i ja chce kierować się zasada „clara pacta faciunt amicos" ${ }^{\text {"57 }}$, za co szczerze przepraszam.

Wołałbym, żebyśmy, zamiast pisać, umieli się zdobyć na powiedzenie prawdy w cztery oczy, po bratersku, lub wobec świadków, tak jak to Chrystus zalecał.

W tej nadziei łącze wyrazy czci i oddania.

Bp Br. Dąbrowski ${ }^{58}$

57 „Jasne układy tworzą wiernych przyjaciół”.

${ }^{58}$ Podpis odręczny. 